\title{
Pemetaan Masalah-Masalah Sumber Daya Manusia Kearsipan Pada Perguruan Tinggi Negeri di Indonesia: Sebuah Studi Teoritis
}

\author{
Tri Handayani ${ }^{\left.1^{*}\right)}$ \\ ${ }^{1}$ Program Studi Ilmu Sejarah, Fakultas Ilmu Budaya, Universitas Diponegoro \\ *)Korespondensi: tri.handayani.undip@gmail.com
}

\begin{abstract}
Humans are one important element in an organization including on the state higher education in Indonesia. The existence of the human element in the conventional or electronic archival is required so that the created archives can be arranged, preserved, disposal, acquired, controlled, and used for various purposes by the user. Indonesia has a Republic of Indonesia Law Number 43/2009 about Archival. That Law regulate about how archives be manage include the punishment if someone against the rule. Archives will be manage correctly by human who have competention and skill in archival. Indonesia still have much of problems in this side. Although Indonesian has Archival Law, but this country still lack in professional human resources on archives or Archivist today. We should do a mapping of the factors that cause problems regarding the implementation of archival human resources policies. The study of theory is used to find out the higher education archival human resources policy problem in Indonesia based on the theory aspect. The results of the study are some of problems can be approached from several aspects of science. The use of that approach expected to solve the problems of archival human resources on the state higher education in Indonesia
\end{abstract}

Keywords: archival human resource; archivists; competention, policy; science; state higher education, theory

\begin{abstract}
Abstrak
Manusia merupakan salah satu unsur penting pada suatu organisasi termasuk di lingkungan perguruan tinggi negeri di Indonesia. Keberadaan unsur manusia dalam penyelenggaraan kearsipan konvensional maupun elektronik diperlukan agar arsip yang diciptakan dapat ditata, dilestarikan, disusutkan, diakuisisi, dikendalikan, dan digunakan untuk berbagai keperluan. Indonesia memiliki Undang-Undang Nomor 43 Tahun 2009 tentang Kearsipan. Undangundang tersebut mengatur tentang bagaimana arsip dikelola termasuk hukuman jika seseorang melanggar undangundang tersebut. Arsip akan dikelola dengan baik oleh orang yang memiliki kempetensi dan keterampilan dalam bidang kearsipan. Meskipun Indonesia memiliki undang-undang kearsipan, tetapi negara ini masih kekurangan sumber daya manusia kearsipan yang professional atau Arsiparis saat ini. Kita sebaiknya melakukan pemetaan tentang faktor-faktor yang menyebabkan masalah tentang implementasi kebijakan sumber daya manusia kearsipan. Kajian teori digunakan untuk memecahkan masalah implementasi kebijakan sumber daya manusia kearsipan di Indonesia didasarkan pada aspek teori. Hasil kajian adalah beberapa masalah dapat didekati dari beberapa pendekatan keilmuan. Penggunaan pendekatan tersebut diharapkan untuk dapat memecahkan masalah implementasi kebijakan sumber daya manusia kearsipan pada perguruan tinggi negeri di Indonesia
\end{abstract}

Kata kunci: sumber daya manusia kearsipan; arsiparis; kompetensi, kebijakan; ilmu pengetahuan; perguruan tinggi negeri; teori

\section{Pendahuluan}

Informasi paling mutakhir tentang sumber daya manusia kearsipan profesional atau Arsiparis di Indonesia disampaikan oleh Dr. Mustari Irawan, MPA selaku Kepala Arsip Nasional Republik Indonesia (ANRI) pada Seminar Nasional Kearsipan yang diselenggarakan oleh Program Studi Diploma III Kearsipan Sekolah Vokasi Universitas Gajah Mada (UGM) pada hari Rabu, 10 Mei 2017. Kepala ANRI pada kesempatan tersebut memaparkan, bahwa di seluruh Indonesia untuk mencukupi kebutuhan sumber daya manusia kearsipan bagi institusi pemerintah di Indonesia saat ini diperlukan 143.630 arsiparis yang 
diperlukan. Tetapi jumlah yang tersedia saat ini hanya 3.241 arsiparis atau 2,25\% dari seluruh kebutuhan. Dengan demikian masih dibutuhkan lagi sejumlah 140.389 arsiparis. Menurutnya masalah tersebut terjadi karena beberapa faktor, yaitu (Humas UGM/Ika, 2017. Indonesia Kekurangan 140 Ribu Arsiparis. https:// www.ugm.ac.id/id/news/13864-indonesia.kekurangan.140.ribu.arsiparis. Diakses 7 Desember 2017):

1) Minimnya minat masyarakat untuk menekuni pekerjaan kearsipan.

2) Pandangan miring mengenai profesi arsiparis sebagai orang-orang terbuang dan "diarsipkan".

3) Belum ada pengakuan terhadap sumber daya manusia kearsipan dalam bentuk pemberian tunjangan profesi khusus bagi pengelola arsip.

4) Profesi ini dianggap kurang menjanjikan masa depan.

5) Sumber daya manusia kearsipan Indonesia belum bulat diakui sebagai suatu profesi sehingga sulit berkembang seperti profesi yang lain.

Masalah tentang minimnya arsiparis di Indonesia sebelumnya pernah sampaikan oleh Dr. Andi Kasman, S.E., M.M selaku Deputi Bidang Pembinaan Kearsipan ANRI sekaligus selaku Ketua Asosiasi Arsiparis Indonesia pada Seminar Nasional Kearsipan dengan tema "Peranan Pengelola Arsip Dalam Menunjang Kinerja Organisasi” yang diselenggarakan oleh Kantor Perpustakaan dan Arsip Kabupaten Kebumen bekerjasama dengan Lembaga Pengembangan Pendidikan Pustaka Indonesia pada tanggal 27 September 2014 di Gedung Juang 45 Kebumen.

Informasi yang dipetik dari kegiatan Seminar Nasional Kearsipan di Kebumen pada tahun 2014 sangat penting untuk kita cermati. Data Arsiparis Indonesia pada ANRI per Oktober tahun 2013 adalah sebagai berikut (Suara Merdeka, 2014. https://lintaskebumen.wordpress.com/2014/09/29/anri-tenaga-arsiparis-diindonesia-masih-minim/. Diakses 7 Desember 2017):

1) Jumlah kebutuhan tenaga Arsiparis secara nasional 142.760 orang

2) Jumlah tenaga Arsiparis yang sudah ada 3.154 orang (2,2\%) dengan rincian 2.981 Arsiparis Pusat dan 1.173 Arsiparis Daerah

3) Dari 3.154 Asiparis yang sudah bersertifikat 216 orang $(5,29 \%)$

Selanjutnya Deputi Pembinaan ANRI menyatakan, bahwa target ANRI pada Tahun 2015 terdapat $35 \%$ dari keseluruhan Arsiparis di Indonesia atau 450 Arsiparis sudah bersertifikat. Adapun pada tahun 2014 juga 450 Arsiparis sudah bersertifikat.

Masalah tentang sumber daya manusia kearsipan di tahun 2012 ternyata juga memiliki pola masalah yang sama. Dr. Andi Kasman, S.E., M.M selaku Deputi Bidang Pembinaan Kearsipan pada Arsip Nasional Republik Indonesia sekaligus selaku Ketua Asosiasi Arsiparis Indonesia pada 15 Mei 2012 di Jakarta menyampaikan, bahwa lembaga kearsipan pemerintah membutuhkan 15.000 arsiparis tetapi jumlah yang tersedia hanya 3.531 arsiparis atau 23,5 persen. Lebih lanjut dikatakan, bahwa kekurangan tenaga arsiparis mengakibatkan arsip milik negara maupun pemerintah menjadi tidak terurus dengan baik. Penyebab dari kurangnya tenaga arsiparis di Indonesia adalah (Kompasiana.com/Indriasari. 2012. Indonesia

Kekurangan Arsiparis. 
http://edukasi.kompas.com/read/2012/05/15/20284782/Indonesia.Kekurangan.Arsiparis.

Desember 2017):

1) Program studi kearsipan di perguruan tinggi sebagai lembaga pendidikan formal yang menyiapkan sumber daya manusia berlatar belakang pendidikan kearsipan sebagaimana diatur dalam Undang-Undang Nomor 43 Tahun 2009 tentang Kearsipan tidak diminati mahasiswa.

2) Profesi sebagai arsiparis dianggap kurang menjanjikan masa depan tidak sebanding dengan tanggung jawab yang harus dilaksanakan termasuk sanksi pidana bila dinggap tidak dapat menjaga rahasia negara.

3) Lingkungan politik yang kurang berpihak pada kesejahteran sumber daya manusia kearsipan. Sebagai pada tahun 2012 pemberian tunjangan profesi bagi arsiparis yang telah lulus sertifikasi belum dapat diberikan. Alasannya adalah karena peraturan pelaksanaan terhadap Peraturan Pemerintah Nomor 28 Tahun 2012 tentang Pelaksanaan Undang-Undang Nomor 43 Tahun 2009 tentang Kearsipan belum ada.

Paparan Deputi Pembinaan Kearsipan Arsip Nasional Republik Indonesia sekaligus Ketua Asosiasi Arsiparis Indonesia sejalan dengan pemikiran Drs. Machmoed Effendhie, M.Hum. yang pada saat tulisan ini diangkat di media massa menjabat selaku Kepala Arsip Universitas Gadjah Mada (UGM) sekaligus dosen pada Program Studi Kearsipan UGM. Menurutnya masalah terkait sumber daya manusia kearsipan di Indonesia adalah (Kompasiana.com/Indriasari. 2012. Indonesia Kekurangan Arsiparis. http://edukasi. kompas.com/read/2012/05/15/20284782/Indonesia.Kekurangan.Arsiparis. Diakses 7 Desember 2017):

1) Program studi Kearsipan tidak diminati siswa. Indikasinya dari lima universitas yang membuka program studi kearsipan, yakni UGM, Universitas Indonesia (Jakarta), Universitas Padjajaran (Bandung), Universitas Hasanuddin (Makassar), dan Universitas Diponegoro (Semarang), terdapat program studi yang terpaksa ditutup karena tidak ada peminatnya.

2) Berkurangnya peluang sarjana kearsipan menduduki jabatan sebagai kepala lembaga kearsipan, karena posisi tersebut ternyata lebih banyak dijabat oleh orang-orang yang kurang berkompeten di bidang kearsipan.

Informasi penting tentang masalah-masalah terkait sumber daya manusia kearsipan di Indonesia selama tahun 2012 hingga 2017 dari pejabat ANRI merupakan catatan penting bagi dunia kearsipan di Indonesia. Strategi penting perlu segera diambil oleh ANRI selaku pembina kearsipan nasional di Indonesia. Kepala ANRI menyampaikan masalah-masalah sumber daya manusia kearsipan di Indonesia kepada Dr.H. Asman Abnur, S.E., M.Si selaku Menteri Pendayagunaan Aparatur Negara dan Reformasi Birokrasi Repubulik Indonesia (Kemenpan dan RB) pada acara Rapat Koordinasi Pembinaan Jabatan Fungsional Arsiparis di Redtop Hotel pada 7 Februari 2017. Tema Rapat Koordinasi tersebut adalah "Pemenuhan Kebutuhan Arsiparis". Melalui forum tersebut diharapkan diperoleh perhatian dari Kemenpan dan RB tentang kondisi riil para "penjaga ketahanan informasi" berbasis arsip. Apabila 
diperoleh kesamaan persepsi terhadap masalah tersebut, maka kedepannya dapat diharapkan Kemenpan dan RB selaku salah satu aktor dalam penentu kebijakan pengadaan sumber daya manusia akan dilanjutkan dengan proses politik bersama-sama Menteri Keuangan atas nama pemerintah mengalokasikan anggaran untuk kepentingan tersebut. Sebuah upaya yang tidak mudah karena keterbatasan anggaran negara ditengah-tengah banyaknya program pembangunan.

Masalah sumber daya manusia kearsipan tidak berhenti pada masalah kebutuhan Arsiparis saja, tetapi juga masalah upaya peningkatan kompetensi mereka. Drs. Machmoed Effendhie, M.Hum. pada kesempatan yang sama mengungkapkan, bahwa SKKNI merupakan kebijakan pemerintah Republik Indonesia yang diatur dalam Peraturan Menteri Ketenagakerjaan Republik Indonesia Nomor 2 Tahun 2016 tentang Sistem Standarisasi Kompetensi Kerja Nasional. Kebijakan ini merupakan penyempurnaan dari Peraturan Menteri Tenaga Kerja dan Transmigrasi Nomor 5 Tahun 2012 tentang Sistem Standarisasi Kompetensi Kerja Nasional.

Kebijakan tentang Peraturan Menteri Ketenagakerjaan Republik Indonesia Nomor 2 Tahun 2016 tentang Sistem Kompetensi Kerja Nasional merupakan pelaksanaan dari Pasal 16 Undang-Undang Nomor 23 Tahun 2014 tentang Pemerintah Daerah. Sebagaimana kita ketahui, bahwa undang-undang tersebut mengatur tentang kewenangan pemerintah pusat dan pemerintah daerah. Merujuk pada bagian konsideran Peraturan Menteri Ketenagakerjaan tersebut diketahui, bahwa keberadaan SKKNI adalah sebagai pendukung pelaksanan pelatihan berbasis kompetensi dan sertifikasi kompetensi. Adapun menurut Pasal 1 angka 2 dijabarkan pengertian SKKNI sebagai rumusan kemampuan kerja yang mencakup aspek pengetahuan, keterampilan, dan/atau keahlian serta sikap kerja yang relevan dengan pelaksanaan tugas dan syarat jabatan yang ditetapkan sesuai dengan ketentuan peraturan perundang-undangan. Kebijakan ini pada prinsipnya mengatur tentang standarisasi setiap kompetensi di bidang pendidikan vokasi/keterampilan, pelatihan kerja, sertifikasi kompetensi kerja serta manajemen dan pengembangan sumber daya manusia. Indonesia sudah memiliki standar kompetensi jabatan fungsional arsiparis, tetapi belum memiliki Standar Kompetensi Kerja Nasional Indonesia (SKKNI) bidang kearsipan.

Keberadaan SKKNI merupakan amanah undang-undang agar tenaga kerja Indonesia memiliki kemampuan daya saing di dunia kerja. Seseorang yang telah memenuhi kualifikasi SKKNI akan mampu (admin, SKKNI:Standar Kompetensi Kerja Nasional Indonesia. https://sertifikasibnsp.com/skkni/skkni/ . Diakses 5 Desember 2017) :

1) Mengerjakan setiap pekerjaan

2) Mengorganisasikan pekerjaan walaupun pekerjaan tersebut berbeda dengan yang direncanakan

3) Mengerjakan pekerjaan dengan kondisi yang berbeda

4) Mengerjakan pekerjaan di segala situasi dan kondisi

Merujuk pada uraian tersebut diketahui bahwa Indonesia perlu memiliki SKKNI bidang kearsipan dengan standar internasional agar para tenaga kerja Indonesia juga mampu bersaing di pasar kerja internasional. Menurut Drs. Machmoed Effendhie, M.Hum. secara ideal proses penyusunan draft atau rancangan SKKNI bidang kearsipan melibatkan para pemangku kepentingan, antara lain pemerintah, 
lembaga sertifikasi, pakar kearsipan, praktisi kearsipan, asosiasi profesi kearsipan, akademisi, stakeholder. SKKNI bidang kearsipan nampaknya sudah sangat mendesak keberadaannya, agar pengadaan sumber daya manusia kearsipan dapat sekaligus sudah berkualifikasi SKKNI bidang kearsipan.

Pengelolaan arsip perguruan tinggi secara eksplisit mulai diatur pada era Undang-Undang Nomor 43 Tahun 2009 tentang Kearsipan. Artinya 38 tahun setelah Undang-Undang Nomor 7 Tahun 1971 tentang Ketentuan-Ketentuan Pokok Kearsipan diundangkan. Tidak heran apabila kebijakan tentang pengadaan, pengembangan, maupun kesejahteraan sumber daya manusia kearsipan perguruan tinggi "dipikirkan" setelah undang-undang tersebut diundangkan, sementara sumber daya manusia kearsipan di lingkungan lembaga negara maupun lembaga pemerintahan pusat maupun daerah secara legal formil sudah dipikirkan sejak tahun 1990 dengan ditetapkannya Keputusan Menteri Negara Pendayagunaan Aparatur Negara Nomor: 36/1990 tentang Angka Kredit Bagi Jabatan Arsiparis atau 19 tahun setelah kebijakan tentang profesionalisasi arsiparis ditetapkan oleh Menteri Negara Pendayagunaan Aparatur Negara pada tanggal 12 Mei 1990. Keberadaan Undang-Undang Nomor 43 Tahun 2009 tentang Kearsipan serta Peraturan Pemerintah Nomor 28 Tahun 2012 tentang Pelaksanaan Undang-Undang Nomor 43 Tahun 2009 tentang Kearsipan memberikan udara segar bagi sumber daya manusia kearsipan karena klausul yang diatur pada kedua perundangan tersebut mengatur lebih tajam diantaranya tentang hak dan kewajiban sumber daya manusia

Pada tataran empiris masalah sumber daya manusia kearsipan di lingkungan lembaga negara maupun lembaga pemerintahan pusat maupun daerah masih dihadapkan pada berbagai masalah, namun pada forum ini penulis akan membatasi diskusi khusus pada pemetaan faktor-faktor yang menyebabkan masalah tentang implementasi kebijakan sumber daya manusia kearsipan pada perguruan tinggi negeri di Indonesia ditinjau dari aspek teoritis.

\section{Tinjauan Literatur}

Implementasi kebijakan kearsipan perguruan tinggi di Indonesia terkait dengan kebijakan publik, kearsipan dan perguruan tinggi. Secara teoritis implementasi terhadap suatu kebijakan dilakukan secara efektif. Dengan demikian pelaksanaan kebijakan dapat terlaksana sesuai dengan tujuan dari diaturnya kebijakan tersebut di dalam perundang-undangan (Suwitri, 2010:9).

Arsip merupakan informasi terekam yang diciptakan oleh suatu lembaga, organiasi maupun perorangan. Perguruan tinggi merupakan lembaga pendidikan tinggi yang potensial menciptakan arsip tridharma perguruan tinggi. Arsip-arsip yang diciptakan harus diorganisir oleh sumber daya manusia profesional kearsipan di lingkungan organisasi kearsipan perguruan tinggi dengan sistem kearsipan agar keberadaannya berdayaguna dan berhasilguna sebagaimana tujuan dari kebijakan penyelenggaraan kearsipan perguruan tinggi (Utomo, 2006: 248; Sukoco, 2007:84-85).

Sumber daya manusia merupakan salah satu unsur di dalam suatu organisasi. Setiap unsur di dalam organisasi memiliki fungsi masing-masing. Seluruh fungsi tersebut merupakan bagian dari suatu 
sistem.

Keberadaan sistem sebagai pengendali organisasi agar organisasi dapat dilaksanakan sesuai dengan tujuan organisasi (Sukoco, 2007: 31). Organisasi kearsipan juga dilaksanakan sesuai dengan sistem kearsipan. Sumber daya manusia kearsipan sebagai salah satu unsur di dalam sistem kearsipan memiliki peran penting bagi terimplementasikannya kebijakan penyelenggaraan kearsipan perguruan tinggi.

Pada bab Pendahuluan telah dibahas tentang sumber daya manusia dihadapkan masalah kompetensi pada pasar kerja. Sebagaimana diketahui, bahwa Masyarakat Ekonomi Asean (MEA) telah dilaksanakan pada akhir tahun 2015 (Kurniatun, Juli 2016, Buletin Khazanah, Vol. 9, no.2, pp 15-30; Azmi, November 2015, Buletin Khazanah. Vol. 8, no. 3, pp 3-20). Ini menunjukkan, bahwa telah terjadi pergeseran paradigma manajemen sumber daya manusia. Pergeseran ditandai dari istilah Manajemen Personalia menjadi Manajemen Sumber Daya Manusia. Pengelolaan sumber daya manusia dapat ditandai dari pola kerjanya. Pola kerja paradigma lama menurut Sudarmanto (2015:24) kurang mendukung budaya kerja. Terjadi jarak yang jelas antar lini. Kondisi ini tidak sehat untuk program pengembangan organisasi. Dampak lebih lanjut adalah kemampuan dan kompetensi sumber daya manusia tidak berkembang. Sementara itu pada paradigma baru nampak pengelolaan sumber daya manusia lebih aktif, antar lini saling bersinergi demikian pula pada visi misi organisasi, hubungan bersifat mitra, iklim kerja yang kondusif untuk menjaga produktivitas kerja. Unsur lain yang juga mengalami pergeseran menurut Zwell adalah tentang penerimaan pegawai baru, fungsi dan model pelatihan, apresiasi terhadap prestasi kerja pegawai. sistem komensasi terakhir adalah corporate culture. Sudarmanto memaknai kata corporate culture sebagai internalisasi budaya tim. Zwell sebagaimana dikutip oleh Sudarmanto (2015:54) menyatakan, bahwa faktor-faktor yang menentukan yang mempengaruhi dan membentuk kompetensi meliputi: kepercayaan dan nilai, keahlian/keterampilan, pengalaman, karakteristik personal, motivasi, isuisu emosional, kapasitas intelektual. Berikut ini adalah tabel tentang tingkat perbaikan kompetensi.

Tabel 1. Tingkat Perbaikan Kompetensi

\begin{tabular}{|l|l|}
\hline Tingkat Perbaikan & $\begin{array}{l}\text { mengembangkan orang lain, efisiensi produksi, kerja tim, } \\
\text { keahlian teknis, orientasi pelayanan, mengelola kinerja }\end{array}$ \\
\hline Agak sulit diperbaiki & $\begin{array}{l}\text { orientasi hasil, kualitas keputusan, pengaruh, penyelesaian } \\
\text { konflik, pemikiran strategis, pemikiran analisis, } \\
\text { kecerdasan organisasional, }\end{array}$ \\
\hline Sulit diperbaiki & $\begin{array}{l}\text { inisiatif, inovasi, integritas dan kejujuran, pengelolaan } \\
\text { tekanan kejiwaan, pemikiran konseptual, fleksibilitas }\end{array}$ \\
\hline
\end{tabular}


Sumber: Zwell didalam Sudarmanto (2015: 57)

Membahas sumber daya manusia kearsipan pada perguruan tinggi negeri tentu perlu dilakukan peninjauan tentang perguruan tinggi (Abbas, 2009:89; Indrajit dan Djoko Pranoto, 2016:1-3). Perguruan tinggi merupakan lembaga pendidikan yang menyelenggarakan pendidikan tinggi. Keberadaannya diatur dalam Undang-Undang Republik Indonesia Nomor 12 Tahun 2012 tentang Pendidikan Tinggi. Adapun Pelaksanaannya diatur dalam Peraturan Pemerintah Republik Indonesia Nomor 4 Tahun 2014 Tentang Penyelenggaraan Pendidikan Tinggi Dan Pengelolaan Perguruan Tinggi.

Kebijakan tentang perguruan tinggi di Indonesia saat ini diatur dalam kebijakan tentang penyelenggaraan pendidikan tinggi yang cukup dinamis sehingga setiap pemangku kepentingan harus senantiasa memperbaharui informasi yang telah dimiliki. Salah satu kebijakan tentang penyelenggaraan pendidikan tinggi di Indonesia dewasa ini terkait status hukum perguruan tinggi. Saat ini kita mengenal adanya perguruan tinggi satuan kerja, perguruan tinggi badan layanan umum, perguruan tinggi negeri badan hukum. Masing-masing status perguruan tinggi tersebut memiliki peraturan pelaksanaan yang berbeda-beda. Salah satu efek dari pembedaan status tersebut adalah terkait langsung dengan teknis pengadaan dan pengembangan sumber daya manusia kearsipan.

\section{Metode Penelitian}

Penelitian ini menggunakan metode kualitatif, yaitu menggunakan dokumen, publikasi teks dan sejenisnya. Tujuan dari penggunaan metode ini adalah untuk menggali nilai perilaku (Herdiansyah, 2011:11). Temuan yang diperoleh didekati dengan berbagai teori keilmuan. Dengan pendekatan ini diharapkan dapat diperoleh solusi terhadap masalah sumber daya manusia kearsipan yang terjadi di Indonesia.

\section{Hasil dan Pembahasan}

Kebijakan tentang penyelenggaraan kearsipan perguruan tinggi merupakan konsep kebijakan yang relatif baru. Dikatakan demikian karena pada era Undang-Undang Republik Indonesia Nomor 7 Tahun 1971 tentang Ketentuan-Ketentuan Pokok Kearsipan, informasi terekam yang direkam di dalam arsip dengan media apapun dan dalam bentuk corak apapun tidak menyebut secara eksplisit tentang informasi terekam yang diciptakan oleh perguruan tinggi khususnya perguruan tinggi negeri. Kebijakan tersebut diatur pada era Undang-Undang Republik Indonesia Nomor 43 Tahun 2009 tentang Kearsipan.

Menyelenggarakan kebijakan bidang kearsipan bukan merupakan perkara mudah bukan hanya bagi bangsa Indonesia. Berbagai penelitian dokumen hasil penelitian penyelenggaran kearsipan perguruan tinggi negeri di Amerika Serikat menunjukkan, bahwa masalah yang mereka hadapi sama dengan masalah di Indonesia. Masalah-masalah tersebut sangat klasik dan mudah didekati dengan model teori implementasi kebijakan publik. Unsur-unsur yang hampir selalu muncul pada masalah implementasi kebijakan publik adalah unsur organisasi, disposisi, komunikasi, sumber daya mencakup: sumber daya manusia, pendanaan, sarana dan prasarana. Satu unsur yang cukup mencolok pada implementasi kebijakan penyelenggaraan kearsipan perguruan tinggi di Indonesia adalah unsur lingkungan politik. 
Sesuai dengan judul penelitian ini maka fokus kajian adalah pada lingkup sumber daya manusia kearsipan.

\section{Sumber Daya Manusia dalam aspek Organisasi}

Organisasi merupakan kelompok sosial lebih dari satu orang yang dikoordinasikan secara sadar, untuk mencapai suatu tujuan. Mereka saling berinteraksi satu sama lain untuk bersama-sama mencapai tujuan tersebut. Untuk keteraturan dalam berinteraksi maka interaksi diantara anggota dibingkai pada suatu struktur organisasi. Didalam tubuh organisasi dibuat kesepakatan-kesepakatan yang wajib diikuti oleh seluruh anggota sebagai landasan hukum "ikatan" diantara mereka dalam berorganisasi. Unsur didalam organisasi meliputi orang, posisi, dan unit-unit organ di dalam organisasi yang tersusun dalam suatu struktur (Kusdi, 2009:168).

Institusi apapun bentuknya pasti memiliki struktur organisasi yang terdiri dari organ-organ terkait satu dengan yang lain, bekerja bersama-sama untuk mencapai tujuan organisasi. Hasil penelitian Kouzes dan Posner pada tahun 1997 (Sudarmanto, 2015:79) menunjukkan, bahwa integritas dan kejujuran merupakan instrumen penting bagi setiap pemimpin yang ingin sukses dalam berkarier. Berikut ini adalah kutipan dari hasil survei yang menanyakan tentang karakteristik pemimpin yang berhasil dan dikagumi. Secara prinsip jawaban yang paling sering disebutkan secara urut adalah sebagai berikut: "(1) integritas, (2) kecakapan, (3) kepemimpinan". Penjabaran dari integritas meliputi sifat pemimpin yang tulus, bisa dipercaya, berwatak, memiliki keyakinan. Selanjutnya kecakapan meliputi sifat pemimpin yang mampu bekerja, produktif dan efisien. Adapun unsur kepemimpinan adalah sifat pemimpin yang mampu menjadi inspirasi bagi lingkungannya, pemimpin yang selalu bersikap pasti, dan pemimpin yang miliki kemampuan dalam memberikan arah bagi lingkungannya)

Lingkup kerja kearsipan memerlukan pemimpin yang berkarakter, karena bekerja dengan arsip memiliki resiko terhadap kesehatan dan keselamatan. Arsip merupakan informasi terekam terhadap setiap peristiwa yang terjadi. Dengan demikian informasi yang yang dikandung di dalam arsip merupakan fakta sekaligus bukti terhadap suatu peristiwa yang terjadi. Dengan alasan tersebut, maka sumber daya manusia kearsipan harus benar-benar menguasai Undang-Undang Nomor 43 Tahun 2009 tentang Kearsipan, Undang-Undang Nomor 14 Tahun 2008 tentang Keterbukaan Informasi Publik, Undang-Undang Nomor 25 Tahun 2009 tentang Pelayanan Publik. Selain itu di era informasi berbasis elektronik saat ini, mereka juga perlu untuk memahami aturan-aturan tentang informasi dan transaksi elektronik sebagaimana diatur dalam Undang-Undang Nomor 11 Tahun 2008. Buku yang berjudul Leading and Managing Archives and Records Programs: Strategy for Success dengan editor BruceW. Dearstyne (2008) memuat kompilasi dari 13 orang praktisi di berbagai bidang pekerjaan yang menulis hasil pengalaman maupun kebijaksanaan mereka tentang kepemimpinan di bidang kearsipan. Salah satunya adalah pengalaman Peter Emmerson (2008:91-113). Sebagai seseorang yang bekerja di dunia perbankan, maka Emmerson membagi pengalamannya tentang arti penting manajer arsip terhadap manajemen arsip perbankan. Manajer arsip bank dituntut untuk siap merespon setiap perubahan dan respon terhadap tujuan strategis dari bisnis yang lebih luas sehingga lembaga dimana dia bekerja dapat tumbuh dan berkembang. 
Perguruan tinggi merupakan lembaga pendidikan tinggi yang memberikan layanan kepada publik dalam penguasaan ilmu strata tinggi setelah sekolah menengah. Misi perguruan tinggi harus mampu mendidik para mahasiswanya menjadi manusia yang terlatih atau berpengetahuan, mampu menjaga warisan budaya dalam sebuah peradaban yang menjunjung tinggi harkat manusia sebagai individu dan anggota kelompok sosial, membentuk para peserta didik yang mampu memahami dirinya sendiri, mampu berperan dalam masyarakat, mampu menjadikan dirinya sebagai manusia yang lebih baik dari sebelumnya (Amir, 2016:1-3)

Perguruan tinggi sebagai organisasi dalam mencapai tujuannya diperlukan tata kelola perguruan tinggi. Tata kelola perguruan tinggi digerakkan oleh berbagai sumber daya yang harus digerakkan secara selaras dengan beban yang seimbang pada setiap organ untuk mencapai arah yang sama. Amir (2016:29) menyatakan, bahwa "untuk menjaga kehidupannya yang sehat perguruan tinggi memerlukan tenaga dalam takaran yang cukup dan terdistribusikan dengan benar". Selanjutnya ia menyebutkan, bahwa "memberikan tenaga kepada setiap organ dalam tubuh organisasi adalah salah satu fungsi dari manajemen".

Sumber daya manusia di lingkungan perguruan tinggi merupakan salah satu unsur dalam sumber daya perguruan tinggi yang meliputi unsur dosen, mahasiswa, karyawan, pimpinan. Unsur lainnya dalam aspek sumber daya di lingkungan perguruan tinggi adalah infrastruktur mencakup sarana dan prasarana, pengetahuan mencakup kekayaan intelektual, keterampilan, kepakaran. Selanjutnya adalah unsur dana, pengakuan pemerintah berupa ijin penyelenggaraan pendidikan tinggi, dukungan masyarakat, dan lainlain Amir (2016:29-30).

Merujuk pada paparan Kusdi (2009:168) kita ketahui bahwa lembaga kearsipan perguruan tinggi merupakan suatu bentuk organisasi yang keberadaannya merupakan bagian dari organisasi pendidikan tinggi yang disebut perguruan tinggi. Keberadaan lembaga kearsipan perguruan tinggi merupakan bagian dari organ khusus dengan tugas dan fungsi mengelola segala sesuatu yang terkait dengan arsip sebagai hasil samping dari kegiatan administrasi.

Penyelenggaraan lembaga kearsipan perguruan tinggi di Indonesia diatur dalam Peraturan Kepala Arsip Nasional Republik Indonesia Nomor 24 Tahun 2011 tentang Pedoman Penyelenggaraan Kearsipan di Lingkungan Perguruan Tinggi. Didalam peraturan tersebut diantaranya dimuat tentang unsur organisasi dan unsur sumber daya manusia sebagai bagian dari Sumber Daya Pendukung. Ditinjau dari unsur organisasi terdapat 3 sub unsur, yaitu Unit Kearsipan I, Unit Kearsipan II, serta Lembaga Kearsipan Perguruan Tinggi. Dengan demikian penempatan sumber daya manusia kearsipan di lingkungan perguruan tinggi ditinjau dari unsur organisasi berada pada ketiga sub organisasi tersebut.

Data penelitian yang penulis miliki menunjukkan, bahwa Universitas Gadjah Mada merupakan contoh perguruan tinggi yang perduli pada arsip sehingga satuan-satuan kerja yang ada pada perguruan tinggi tersebut telah memiliki sumber daya manusia kearsipan. Data sebaran sumber daya manusia kearsipan di lingkungan Kantor Pusat UGM yang diperoleh peneliti dari Bidang Database Arsip UGM, 
tanggal 11 Agustus 2015 menunjukkan dari 14 satuan kerja di lingkungan kantor pusat UGM semuanya telah memiliki sumber daya manusia kearsipan. Khusus pada Arsip Universitas terdapat tujuh Arsiparis dan tiga Pengelola Arsip. Sementara 13 satuan kerja yang lain masin-masing memiliki satu orang Pengelola Arsip. Sementara itu pada waktu yang sama sebaran sumber daya manusia kearsipan di lingkungan akademik menunjukkan 19 fakultas dan Magister Administrasi Publik telah memiliki Arsiparis dan/atau Pengelola Arsip. Arsiparis dan Pengelola Arsip terdapat di Fakultas Biologi satu orang, Farmasi 3 orang, Kedokteran 1 orang, MIPA 1 orang, Pertanian dua orang, Peternakan satu orang, Psikologi satu orang. Selanjutnya 19 fakultas dan Magister Administrasi Publik telah memiliki Pengelola Arsip dengan rincian satu sampai tiga orang. Jumlah keseluruhan adalah 10 Arsiparis dan 21 Pengelola Arsip. Prestasi ini perlu mendapatkan apresiasi karena menunjukkan komunikasi pimpinan Arsip UGM selaku pembina kearsipan di lingkungan UGM dengan pimpinan UGM dan pimpinan satuan kerja di lingkungan UGM berhasil dilakukan.

Status hukum perguruan tinggi negeri badan hukum yang melekat pada UGM mempunyai konsekuensi bagi pengelola lembaga kearsipan perguruan tinggi untuk aktif dan kreatif. Setiap program yang direncanakan dituntut untuk memiliki luaran yang jelas, terukur dan memiliki manfaat secara luas. "Menunjukkan karya daripada bicara" nampaknya patut disebut sebagai "bahasa komunikasi" yang efektif. Luaran dari program Arsip UGM yang terus berkembang dan berkesinambungan sebagai nampak pada informasi program Arsip UGM yang dipublikasikan melalui media publikasi Khazanah merupakan instrumen komunikasi penting yang ditransmisikan kepada seluruh pihak pemangku kepentingan.

Arsip UGM merupakan Lembaga Kearsipan Perguruan Tinggi UGM didirikan tanggal 11 September 2004 melalui SK Rektor No.249/P/SK/HT/2004. Selama kurun waktu 2004 hingga 2016 organisasi kearsipan ini telah meraih prestasi yang menurut peneliti dapat diraih apabila organisasi tersebut melaksanakan tata kelola organisasi dengan baik. Data capaian prestasi yang diolah oleh peneliti dari website resmi UGM dan bagian Database Arsip UGM pada tanggal 10 Mei 2017 menunjukkan hasil sebagai berikut:

1) Tahun 2007 Arsip UGM sebagai lembaga kearsipan perguruan tinggi meraih predikat sebagai Teladan I Tingkat Nasional Unit Pengelola Kearsipan Perguruan Tinggi Negeri oleh Kementerian Pendidikan Nasional

2) Tahun 2009 Zaenudin sebagai Arsiparis pada Arsip UGM meraih predikat Teladan II Tingkat Nasional oleh Kementerian Pendidikan dan Kebudayaan atas nama Zaenudin

3) Tahun 2010 Herman Setyawan sebagai Arsiparis pada Arsip UGM meraih predikat Teladan I Tingkat Nasional Unit Pengelola Kearsipan Perguruan Tinggi Negeri oleh Kementerian Pendidikan Nasional

4) Tahun 2011 Arsip UGM mempertahankan predikat sebagai pengelola kearsipan terbaik Kementerian Pendidikan Nasional Tahun 2011

5) Tahun 2012 Musliicah sebagai Arsiparis Arsip UGM meraih penghargaan sebagai Arsiparis Terbaik Nasional oleh Kementerian Pendidikan dan Kebudayaan 
6) Tahun 2015 Arsip UGM meraih Predikat sebagai Arsip Perguruan Tinggi Terbaik Nasional

7) Tahun 2015 Arsip UGM meraih Akreditasi Tertinggi dari ANRI

8) Tahun 2016 Zaenudin sebagai Arsiparis UGM meraih Juara I Karya Tulis Kearsipan 2016 Nasional pada kategori Sumber Daya Manusia Kearsipan Instansi Pemerintah dan Swasta, Pusat, Daerah, BUMN dan BUMD.

9) Tahun 2016 Kurniatun sebagai Arsipais UGM meraih Juara II Karya Tulis Kearsipan 2016 Nasional pada kategori Sumber Daya Manusia Kearsipan Instansi Pemerintah dan Swasta, Pusat, Daerah, BUMN dan BUMD.

Seluruh apresiasi tersebut tidak akan diraih tanpa dukungan dari pimpinan Arsip UGM, seluruh sumber daya manusia yang dimiliki Arsip UGM serta pimpinan UGM. Penelitian Kouzes dan Posner pada tahun 1997 sebagaimana dikutip oleh Sudarmanto (2015:79) menunjukkan, bahwa pemimpin yang berintegritas, cakap dan menginspirasi akan membangun kepercayaan tim kerjanya karena ia akan meaksanakan apa yang diucapkan.

Bukti pelaksanaan program menjadi modal bagi pengelola lembaga kearsipan perguruan tinggi dalam mengajukan rancangan program dan anggarannya. Apresiasi dari lingkungan UGM terhadap implementasi kebijakan penyelenggaran kearsipan perguruan tinggi oleh Arsip UGM ditunjukkan dengan dibentuknya Unit-Unit Kearsipan II pada satuan-satuan kerja yang ada beserta sumber daya manusia kearsipan. Publikasi resmi Arsip UGM yang juga dipublikasi melalui jaringan website UGM menunjukkan, bahwa Setiap Unit Kearsipan II rutin menyerahkan arsip statis ke Arsip UGM. Keteraturan tersebut menunjukkan komunikasi yang dilakukan sangat efektif, karena meyakinkan seseorang untuk mempercayakan arsip kepada pihak lain bukan masalah yang mudah.

Implementasi serupa juga terjadi di Arsip Universitas Indonesia. Secara de facto Kantor Arsip UI telah dirintis sejak tahun 2000, namun baru berpayung hukum pada tahun 2009 melalui Surat Keputusan Rektor Nomor 70/PT02.H/U/2009 tentang Pembentukan Tim Lembaga Kearsipan Universitas Indonesia. Dari peta permasalahan yang teridentifikasi, tim menyusun draft pedoman-pedoman yang diperlukan dalam kegiatan pengelolaan arsip (Batubara, 2010. http://leuwiliangbogor.blogspot.com/2010/05/kebijakan-manajemen-arsip-di.html. Diakses 12 Maret 2014; Wawancara dengan Anon Mirmani 25 Oktober 2015). Kerja keras tim ini menjadikan UI meraih prestasi sebagai Teladan Kedua Pengelolaan Arsip Perguruan Tinggi yang diselenggarakan oleh Kementerian Pendidikan dan Kebudayaan bekerjasama dengan ANRI pada tahun 2007. Pada saat itu penyelenggaraan fungsi kearsipan belum memiliki payung hukum dari pimpinan universitas, karena embrio Arsip Universitas Indonesia dibentuk atas inisiatif dari Anon Mirmani selaku pengajar pada Fakultas Ilmu Pengetahuan Budaya Universitas Indonesia (Arsip Universitas Indonesia, 2014 http://arsip.ui.ac.id/tupoksi Diakses 23 Maret 2014).

Sumber Daya Manusia merupakan salah satu faktor dari Sumber Daya Pendukung suatu organisasi. Universitas Indonesia sebelum tahun 2005 hanya memiliki seorang pengelola arsip di Fakultas Sastra 
(sekarang FIB). Universitas ini pada tahun 2005 menambah satu orang dengan kompetensi kearsipan dengan tugas mengolah, menyimpan, dan menyajikan arsip statis. Tahun 2006 menambah dua orang dengan tugas mengolah, menyimpan, dan menyajikan arsip inaktif yang diciptakan oleh pimpinan universitas di PAUI. Setelah itu PAUI bertambah empat orang namun pensiun sekitar tahun 2014. Data terbaru yang diakses pada 17 Mei 20017 dari http://arsip.ui.ac.id/tupoksi-slide 10 menunjukkan, bahwa Universitas Indonesia pada tahun 2016 telah memiliki 46 Arsiparis dan 10 tenaga pengelola arsip. Saat ini jumlah tersebut telah berkurang dua orang tenaga kontrak karena resign. Meskipun demikian dua orang Arsiparis dari unsur pegawai negeri sipil telah tersertifikasi Arsip Nasional Republik Indonesia.

Pelatihan, workshop, seminar dan sejenisnya merupakan upaya yang dilakukan oleh seseorang untuk meningkatkan kemampuan kompetensinya. Demikian pula dengan upaya pimpinan UI untuk meningkatkan kemampuan kompetensi para pegawai terkait dengan bidang kearsipan. Beberapa kegiatan yang dilakukan antara lain sebagaimana paparan berikut: (1) PAUI mengirimkan pengelola arsip di lingkungan PAUI mengikuti pelatihan agar mereka memiliki kemampuan lebih di bidang kearsipan (Batubara. 2010. http://www.leuwiliang-bogor-blogspot.com/2010/05/ kebijakan-manajemen-arsipdi.html). (2) Kantor Arsip Universitas Indonesia bekerja sama dengan Arsip Nasional Republik Indonesia melakukan pelatihan bagi para pengelola arsip di lingkungan UI (Arsip Universitas Indonesia, 2017. Kompetensi, http://arsip.ui.ac.id/node/29. Diakses 17 Mei 2017).

Kantor Arsip Universitas Indonesia telah dua kali mendapatkan penghargaan. Unit Kerja ini pada tahun 2007 meraih Teladan Kedua Pengelolaan Arsip Perguruan Tinggi yang diselenggarakan oleh Kementerian Pendidikan dan Kebudayaan bekerjasama dengan ANRI. Selanjutnya pada tahun 2012 unit kerja ini meraih Teladan Kedua Pengelola Arsip Perguruan Tinggi yang diselenggarakan oleh ANRI. Penghargaan yang diperoleh merupakan apresiasi terhadap capaian kinerja Kantor Arsip Universitas Indonesia dan kerjasama seluruh civitas akademika Universitas Indonesia dalam pengelolaan arsip perguruan tinggi.

ANRI di era Undang-Undang Nomor 43 Tahun 2009 tentang Kearsipan terus berbenah dengan menyiapkan instrumen-instrumen penting sebagai acuan bagi seluruh penyelenggara kearsipan dari pusat hingga daerah untuk dapat menyusun kebijakan terkait di lingkungan kerja masing-masing termasuk di lingkungan perguruan tinggi negeri. Namun tidak demikian halnya dengan di perguruan tinggi negeri di negara bagian Illinois. Keberadaan NSPK sangat penting bagi sumber daya manusia yang mengelola arsip, karena keberadaan mereka merupakan penunjuk arah bagi sumber daya manusia pengelola arsip dalam menjalankan tugas dan fungsinya.

Sarana dan Prasarana merupakan dua hal yang juga menjadi bagian dari komponen sumber daya. Pengembangan sumber daya manusia serta pengembangan sarana dan prasarana tidak lepas dari masalah pendanaan. Sebagaimana telah disampaikan sebelumnya, bahwa saat ini di Indonesia terdapat perguruan tinggi negeri dengan status badan hukum, badan layanan umum dan satuan kerja. Diantara ketiga status hukum perguruan tinggi negeri tersebut, diketahui perguruan tinggi negeri badan hukum paling fleksibel dibanding kedua status hukum perguruan tinggi negeri lainnya. Meskipun demikian, didalam pengajuan 
perencanaan program dan anggaran kerja tetap dilakukan strategi komunikasi agar rancangan program kerja beserta anggarannya mendapatkan persetujuan.

\section{Sumber Daya Manusia Kearsipan pada aspek Manajemen Publik}

Perguruan tinggi negeri merupakan perguruan tinggi yang tata kelolanya langsung dibawah koordinasi Kementerian Riset, Teknologi dan Pendidikan Tinggi. Perguruan tinggi merupakan wujud dari organisasi dengan tugas dan fungsi sebagai lembaga yang menyediakan layanan pendidikan tinggi. Gerlof sebagaimana dikutip oleh Kusdi (2009: 4) menyatakan, bahwa organisasi memiliki karakter 3 P, yaitu Purposes, People, Plan. Artinya setiap organisasi pasti memiliki tujuan, sumber daya manusia, rencana. Disisi lain E. Wight Bakke sebagaimana dikutip oleh Dunsire (Kusdi; 2009:5) diantaranya menyatakan bahwa organisasi merupakan kesatuan dari manusia, material, modal, gagasan, dan sumber daya alam dengan tujuan memecahkan masalah yang dihadapi manusia. Dari paparan tersebut diketahui, bahwa sumber daya manusia adalah unsur yang ada disetiap organisasi karena mereka adalah aset penting yang menggerakan organisasi.

Perguruan tinggi negeri sebagai lembaga pendidikan tinggi yang dinaungi oleh pemerintah memiliki kewajiban untuk memberika layanan yang sebaik mungkin kepada publik. Manajemen publik pada paradigm lama telah berganti-ganti paradigm. Fungsi-fungsi manajemen meliputi planning, organizing, staffing, directing, coordinating, reporting, budgeting (Keban didalam Tri Handayani, 2012:49). Pada perkembangannya era paradigma lama berkembang menuju era manajemen publik baru hingga era pelayanan publik baru. Unsur sumber daya manusia yang terorganisir dan diikat dengan kesepakatan bersama untuk mencapai tujuan selalu hadir dalam manajemen publik. Dinamika pelayanan publik terus bergerak dan memasuki ranah kebijakan di bidang kearsipan.

Upaya memberikan layanan terbaik bidang kearsipan kepada publik membawa sumber daya manusia kearsipan pada kebijakan-kebijakan yang mendorong sumber daya manusia kearsipan pada pengembangan kompetensi. Pelayanan publik sebagaimana diatur dalam Pasal 1 ayat (1) UndangUndang Nomor 25 Tahun 2009 tentang Pelayanan Publik adalah kegiatan pelayanan publik yang diberikan oleh lembaga pelayanan publik setiap warga negara dan penduduk atas barang, jasa, dan/atau pelayanan administrasi. Penyelenggara pelayanan publik sebagaimana diatur dalam Pasal 1 ayat (2) meliputi "setiap institusi penyelenggara negara, korporasi, lembaga independen yang dibentuk berdasarkan undang-undang untuk kegiatan pelayanan publik, dan badan hukum lain yang dibentuk semata-mata untuk kegiatan pelayanan publik.

Pelayanan publik pada konteks kearsipan terkait dengan Undang-Undang Nomor 14 Tahun 2008 tentang Keterbukaan Informasi Publik. Kebijakan kearsipan sebagai salah satu basis informasi tidak serta merta melayankan seluruh informasi yang diminta oleh calon penggunanya. Sumber daya manusia kearsipan wajib untuk memahami konteks kebijakan tersebut agar tidak terjadi kesalahan dalam memberikan layanan kepada para pengguna arsip yang menjadi tanggung jawabnya. Bagan Klasifikasi Informasi Publik menurut Undang-Undang Nomor 14 Tahun 2008 tentang Keterbukaan Informasi Publik 
memberikan tuntunan kepada seluruh pegawai yang memberikan layanan informasi kepada publik tentang landasan pemberian layanan informasi. Bagan dimaksud dapat dilihat pada Bagan 1.

Arsip merupakan salah satu informasi, tetapi arsip bukan buku yang memang keberadaannya untuk dibaca oleh umum. Arsip melalui proses penciptaannya terbagi menjadi arsip rahasia, arsip vital, arsip penting, arsip biasa. Arsip yang telah selesai masa penggunaan administrasinya tetapi memiliki nilaiguna kebuktian dan nilaiguna informasional diserahkan ke lembaga kearsipan untuk diolah dan dilayankan kepada publik. Merujuk pada label yang diberikan kepada arsip yang diciptakan, maka kita dapat langsung menunjukkan kriteria arsip yang dapat dilayankan kepada publik dan yang harus melalui proses penyaringan terlebih dahulu siapa yang akan menggunakannya.

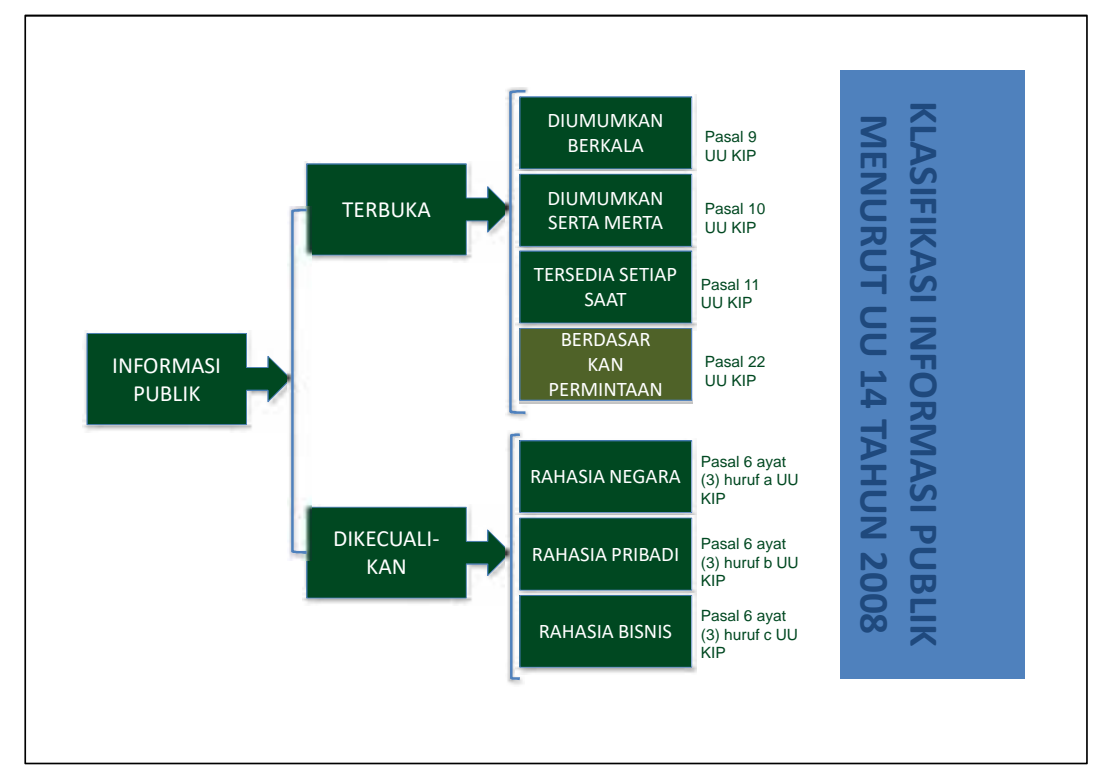

Bagan 1. Klasifikasi Informasi Publik Menurut Undang-Undang Nomor 14 Tahun 2008 tentang Keterbukaan Informasi Publik

Sumber: Bahrun Effendi, 2008. Materi Sosialisasi Undang-Undang Nomor 43 Tahun 2009 tentang Kearsipan - Undang-Undang Nomor 14 Tahun 2008 tentang Keterbukaan Informasi Publik di Daerah. Grobogan, 8 November 2011

Perguruan tinggi merupakan lembaga yang menyelenggarakan pendidikan tinggi melalui tridharma perguruan tinggi. Berdasar pada tugas dan fungsi perguruan tinggi dapat kita ketahui, bahwa selain menciptakan arsip tridharma perguruan tinggi sebagai informasi terekam dari kegiatan tersebut, maka 
perguruan tinggi juga menciptakan arsip administrasi pimpinan sebagai informasi terekam yang merekam kebijakan-kebijakan pimpinan perguruan tinggi. Sumber daya manusia kearsipan perguruan tinggi juga dituntut untuk memahami aspek hukum dari Undang-Undang Nomor 43 Tahun 2009 tentang Kearsipan, Undang-Undang Nomor 14 Tahun 2008 tentang Keterbukaan Informasi Publik, Undang-Undang Nomor 25 Tahun 2009 tentang Pelayanan Publik serta peraturan-peraturan yang mengatur tentang kebijakan internal perguruan tinggi. Sehubungan dengan tugas dan fungsi sumber daya manusia kearsipan, maka mereka perlu untuk diberikan bimbingan teknis, kursus, pendidikan dan pelatihan serta kesempatan untuk mendapatkan pendidikan formal bidang kearsipan untuk semain meningkatkan keterampilan dalam mengelola arsip dan keahlian untuk meningkatkan sistem kearsipan setempat agar semakin handal. Sudarmanto (2015: 76) berpendapat, bahwa integritas merupakan salah satu komponen bagi setiap individu karena keberadaannya akan mendasari dan mengaitkannya dengan kompetensi lainnya. Pemimpin yang berintegritas selalu memahami kebutuhan mendasar organisasi yang dipimpin dan memberikan jalan kepada sumber daya manusia yang dipimpin untuk maju dan berkembang, serta turut memajukan organisasi bersama-sama sebagai suatu tim kerja. Penelitian yang dilakukan oleh Michael Zwell pada tahun 2000 menunjukkan, bahwa integritas dan kejujuran sebagai dimensi penting dalam membangun integritas.

\section{Sumber Daya Manusia Kearsipan pada aspek Kebijakan Publik}

Merujuk pada dinamika politik pemerintah nampaknya kita perlu mencermati pernyataan Kepala ANRI tersebut pada bab Pendahuluan, apakah benar kelima faktor tersebut yang menjadi masalah pengadaan sumber daya manusia profesional kearsipan atau arsiparis? Merujuk pada Pasal 1 angka 6 Peraturan Menteri Pendayagunaan Aparatur Negara dan Reformasi Birokrasi Republik Indonesia Nomor 48 Tahun 2014 tentang Jabatan Fungsional Arsiparis diketahui bahwa "Arsiparis" adalah jabatan fungsional yang dijabat oleh seseorang yang berstatus sebagai pegawai negeri sipil. Jabatan fungsional ini diperoleh melalui jenjang pendidikan formal dan/atau pendidikan dan pelatihan kearsipan. Fungsi, tugas dan tanggung jawab mereka adalah melaksanakan kegiatan kearsipan. Mereka menduduki jabatan fungsional tersebut setelah diangkat oleh pejabat berwenang di lingkungan kedinasan mereka.

Terkait persyaratan status sebagai pegawai negeri sipil untuk dapat menduduki jabatan fungsional Arsiparis, maka faktor politik berupa kebijakan pemerintah menjadi faktor kunci bagi terselenggaranya kebijakan pengadaan Aparatur Sipil Negara. Selanjutnya mereka dengan latar belakang pendidikan formal di bidang kearsipan atau mereka dengan latar belakang pendidikan formal non bidang kearsipan dan telah mendapatkan pendidikan dan pelatihan bidang kearsipan dapat mengajukan persyaratan untuk diangkat sebagai Arsiparis.

Sebagaimana kita ketahui, bahwa undang-undang kearsipan telah di undangkan sejak tahun 1971 melalui Undang-Undang Republik Indonesia Nomor 7 Tahun 1971 tentang Ketentuan-Ketentuan Pokok Kearsipan. Pada Pasal 6 huruf b undang-undang tersebut diatur tentang pendidikan kader ahli kearsipan. Aturan ini lebih mengarah kepada pendidikan kearsipan bagi pegawai pada saat itu yang sudah berstatus 
sebagai pegawai negeri sipil untuk dididik di bidang kearsipan. Selanjutnya pada Pasal 7 ayat (1) disebutkan, bahwa "Pemerintah mengadakan, mengatur dan mengawasi pendidikan tenaga ahli kearsipan. Ayat ini lebih mengarah kepada penyelenggaraan pendidikan keahlian bidang kearsipan. Dengan demikian pemerintah sudah memikirkan tentang arti penting keberadaan lembaga pendidikan formal bidang kearsipan. Pemerintah mengadakan, mengatur dan mengawasi lembaga pendidikan tersebut agar sesuai dengan tujuan kebijakan tentang kearsipan. Sehubungan dengan tugas dan fungsi tenaga fungsional Arsiparis, maka pada Pasal 1 ayat (2) diatur tentang kewenangan pemerintah untuk mengatur kedudukan hukum dan kewenangan tenaga ahli kearsipan. Dengan demikian pemerintah telah mempertimbangkan pengaturan tentang status tenaga fungsinal Arsiparis beserta kewenangan mereka. Aturan ini memberikan jaminan sekaligus perlindungan secara hukum terhadap tenaga fungsional Arsiparis dalam pelaksanaan tugasnya. Sementara itu pada ayat (3) diatur upaya-upaya khusus untuk pemberian jaminan kesehatan kepada para tenaga ahli kearsipan yang disesuaikan dengan fungsi serta tugas dalam lingkungan kerja mereka. Pemerintah dengan aturan tersebut berupaya memberikan jaminan perlindungan bagi kesehatan mereka yang diperkirakan terjadi sebagai akibat dari pelaksanaan tugas mereka.

Zaman telah berubah dan undang-undang kearsipanpun juga bergerak mengikuti arus era reformasi dan pemerintahan yang dinamis yang sudah mendunia. Untuk dapat menyelaraskan dengan dinamika politik di dalam negeri dan di luar negeri, maka Undang-Undang Republik Indonesia Nomor 7 Tahun 1971 tentang Ketentuan-Ketentuan Pokok Kearsipan digantikan dengan Undang-Undang Republik Indonesia Nomor 43 Tahun 2009 tentang Kearsipan yang mulai berlaku sejak diundangkan pada tanggal 23 Oktober 2009.

Undang-Undang Republik Indonesia Nomor 43 Tahun 2009 tentang Kearsipan telah memberikan definisi yang jelas tentang Arsiparis sebagaimana diatur pada Pasal 1 angka 10, bahwa "Arsiparis adalah seseorang yang memiliki kompetensi di bidang kearsipan yang diperoleh melalui pendidikan formal dan/atau pendidikan dan pelatihan kearsipan serta mempunyai fungsi, tugas, dan tanggung jawab melaksanakan kegiatan kearsipan”. Pemerintah juga telah mengatur tentang pengembangan sumber daya manusia kearsipan sebagaimana diatur pada Pasal 30. Merujuk pada Pasal 30 ayat (1) diketahui, bahwa sumber daya manusia kearsipan terdiri dari dua kategori yaitu Arsiparis dan Sumber Daya Manusia yang memiliki kompetensi dan profesionalitas di bidang kearsipan. Selanjutnya pada ayat (2) diketahui, bahwa pembinaan yang dilakukan oleh lembaga kearsipan nasional diupayakan melalui: pengadaan arsiparis; pengembangan kompetensi dan keprofesionalan arsiparis melalui penyelenggaraan, pengaturan, serta pengawasan pendidikan dan pelatihan kearsipan; pengaturan peran dan kedudukan hukum arsiparis; dan penyediaan jaminan kesehatan dan tunjangan profesi untuk sumber daya kearsipan.

Pelaksanaan terhadap kebijakan pengembangan sumber daya manusia kearsipan sebagaimana diatur pada Pasal 30 ayat (1) Undang-Undang Nomor 43 Tahun 2009 tentang Kearsipan diatur dalam Pasal 149 ayat (1), (2), (3) Peraturan Pemerintah Republik Indonesia Nomor 28 Tahun 2012 tentang Pelaksanaan Undang-Undang Nomor 43 Tahun 2009 tentang Kearsipan. 
Merujuk pada uraian tentang sumber daya manusia kearsipan dan upaya pengembangannya diketahui, bahwa pemerintah telah mengatur tentang sumber daya manusia kearsipan melalui kedua undang-undang tentang kearsipan yang pernah berlaku dan sedang berlaku di Indonesia. Artinya adalah kebijakan tentang sumber daya manusia kearsipan baik yang berstatus dengan jabatan fungsional Arsiparis atau sumber daya manusia kearsipan yang mendapatkan keterampilan maupun pelatihan di bidang kearsipan semuanya bermuara pada kebijakan pemerintah. Kebijakan pemerintah didasarkan pada pertimbangan Menteri terkait, yaitu Menteri Pendayagunaan Aparatur Sipil Negara dan Reformasi Birokrasi serta Menteri Keuangan. Kebutuhan sumber daya manusia kearsipan untuk lingkungan Kementerian Riset, Teknologi, dan Pendidikan Tinggi termasuk didalamnya untuk mencukupi kebutuhan sumber daya manusia kearsipan di perguruan tinggi-perguruan tinggi negeri yang ada di Indonesia juga terkait dengan kementerian yang mengkoordinir perguruan tinggi negeri. Kebutuhan sumber daya manusia kearsipan selanjutnya melalui proses politik pembahasan di lembaga legislatif.

Berdasar kepada uraian tentang sumber daya manusia kearsipan dan pengembangannya dapat kita ketahui, bahwa pernyataan Kepala ANRI tentang latar belakang masalah Indonesia kekurangan Arsiparis kurang lengkap. Menurut peneliti faktor lingkungan politik juga memiliki andil yang cukup signifikan sebagai penyumbang masalah kurangnya sumber daya manusia kearsipan di Indonesia. Faktor ini memiliki andil yang cukup besar dalam kebijakan pengadaan sumber daya manusia kearsipan dan pengembangannya.

Peneliti telah mengakses data jumlah perguruan tinggi negeri di Indonesia yang dinaungi oleh Kementerian Riset, Teknologi dan Pendidikan Tinggi Republik Indonesia. Merujuk pada data dari Direktorat Jenderal Pendidikan Tinggi Kementerian Riset, Teknologi, dan Pendidikan Tinggi Indonesia melalui alamat website http://www.dikti.go.id/perguruan-tinggi/ dan diakses peneliti tanggal 4 April 2017 diketahui jumlah perguruan tinggi negeri di Indonesia pada saat itu adalah adalah 122 perguruan tinggi. Kebijakan pemerintahan dinamis yang dianut pemerintah Indonesia mengantarkan perguruan tinggi negeri di Indonesia dibedakan menjadi Perguruan Tinggi Negeri Badan Hukum (PTNBH), Perguruan Tinggi Negeri Badan Layanan Umum (PTN-BLU), Perguruan Tinggi Negeri Satuan Kerja (PTN-Satker). Pemerintah mengundangkan Peraturan Pemerintah Republik Indonesia Nomor 61 Tahun 1999 tentang Penetapan Perguruan Tinggi Negeri Sebagai Badan Hukum (PTN-BHMN). Disaat yang hampir bersamaan lahir Perguruan Tinggi Negeri Badan Layanan Umum (PTN BLU). Penetapan PTNBLU dilakukan dengan Keputusan Menteri Keuangan atas usul Menteri Pendidikan dan Kebudayaan (sekarang Menteri Riset, Teknologi dan Pendidikan Tinggi) (Wikipedia, 2017. Perguruan Tinggi Negeri Badan Hukum. https://id.wikipedia.org/wiki/Perguruan_Tinggi_Negeri_Badan_Hukum). Perguruan tinggi negeri dengan status Satuan Kerja (Satker) merupakan jumlah yang mendominasi dari 122 perguruan tinggi negeri yang ada saat ini. Distribusi status hukum perguruan tinggi negeri di Indonesia saat ini adalah PTN-BH telah mencapai 11 PTN, PTN-BLU sebanyak 24 PTN, dan PTN Satuan Kerja (PTN- 
Satker) mencapai 86 PTN (Fitri, 2016. Seputar PTN-BH, PTN-BLU, PTN-Satker dan PTN-Baru. http://www.kopertis12.or.id/2016/05/16/seputar-ptn-bh-ptn-blu-ptn-satker-dan-ptn-baru.html).

Status hukum perguruan tinggi berdampak cukup signifikan terhadap perguruan tinggi negeri Satuan Kerja dengan perguruan tinggi negeri Badan Hukum dan Badan Layanan Umum. Pada aspek pengembangan sumber daya manusia, perguruan tinggi negeri PTN-BH lebih leluasa untuk merekrut sendiri sesuai dengan kemampuan modal anggaran belanja pegawai perguruan tinggi tersebut. Meskipun demikian kita tidak akan meninggalkan aturan pada pada Pasal 1 angka 6 Peraturan Menteri Pendayagunaan Aparatur Negara dan Reformasi Birokrasi Republik Indonesia Nomor 48 Tahun 2014 tentang Jabatan Fungsional Arsiparis, bahwa "Arsiparis" adalah jabatan fungsional yang dijabat oleh seseorang yang berstatus sebagai pegawai negeri sipil. Dengan demikian perguruan tinggi negeri dengan status badan hukum juga tetap tidak leluasa untuk mendapatkan Arsiparis. Otoritas perguruan tinggi negeri pada umumnya mengangkat pegawai non Pegawai Negeri Sipil atau menugaskan pegawai negeri sipil untuk melaksanakan tugas dan fungsi sebagaimana seorang dalam jabatan sebagai Arsiparis. Kebijakan ini telah berlangsung di lingkungan Universitas Gadjah Mada maupun Universitas Indonesia.

Faktor politik yang berdampak pada kebijakan pemerintah di bidang sumber daya manusia kearsipan menunjukkan, bahwa Pemerintah Republik Indonesia terus menyesuaikan kebijakan terkait sumber daya manusia kearsipan. Peneliti mencatat kebijakan yang terbaru antara lain Peraturan Kepala Arsip Nasional Republik Indonesia (Perka ANRI) Nomor 6 Tahun 2017 tentang Tata Cara Pengangkatan Pegawai Negeri Sipil Dalam Jabatan Fungsional Arsiparis Melalui Penyesuaian/Inpassing, Peraturan Menteri PendayagunaanAparatur Negara dan Reformasi Birokrasi (Permenpan dan RB) Nomor 26 Tahun 2016 tentang Pengangkatan Pegawai Negeri Sipil dalam Jabatan Fungsional melalui Penyesuaian/Inpassing, Peraturan Kepala Badan Kepegawaian Negara Nomor 24 Tahun 2016 tentang Petunjuk Teknis Pelaksanaan Pembinaan Jabatan Fungsional Arsiparis, Peraturan Menteri Pendayagunaan Aparatur Negara dan Reformasi Birokrasi Republik Indonesia Nomor 13 Tahun 2016 tentang Perubahan Atas Peraturan Menteri Pendayagunaan Aparatur Negara dan Reformasi Birokrasi Republik Indonesia Nomor 48 Tahun 2014 tentang Jabatan Fungsional Arsiparis, Surat Kepala Arsip Nasional Republik Indonesia Nomor HK.O1.00/3160/2016 Tanggal 1 Desember 2016. Namun sebagaimana disampaikan oleh Drs. Machmoed Effendhie, M.Hum., bahwa Indonesia belum memiliki SKKNI agar sumber daya manusia bidang kearsipan memiliki daya saing di pasar kerja lokal, regional, nasional maupun internasional. Kebijakan ini perlu untuk segera dirumuskan dan direalisasikan, agar sumber daya manusia kearsipan Indonesia semakin meningkat kompetensinya dan mampu bersaing di bursa tenaga kerja global.

\section{Sumber Daya Manusia Kearsipan pada aspek Budaya}

Keesing (1999:67-68) mengartikan budaya sebagai himpunan pengalaman yang dipelajari. Definisi ini begitu terbuka karena setiap antropolog memiliki sudut pandang yang tidak selalu sama tentang budaya. Diantaranya menyebut unsur dalam budaya antara lain perilaku, adat istiadat, kepercayaan, hukum, nilai-nilai yang dipelajari dan diwariskan, dan lain-lain. Organisasi sebagai 
kumpulan dari orang-orang yang mengikat diri mereka untuk mencapai tujuan yang sama juga memiliki budaya yang disebut sebagai budaya organisasi.

Sudarmanto (2015:164-166) menyebutkan bahwa konsep tentang budaya organisasi sudah mulai populer sejak awal tahun 1980-an. Budaya organisasi didalam ilmu manajemen dikenal sebagai corporate culture. Merujuk pada pengertian budaya sebagaimana disampaikan oleh para antropolog, maka pengertian budaya organisasi antara juga menyangkut tentang sikap, nilai-nilai, norma perilaku para anggota organisasi yang telah melembaga. Wujudnya berupa penampilan, sikap, dan tindakan yang kemudian menjadi identitas dari masing-masing organisasi.

Simpulan yang diambil oleh peneliti adalah profile setiap lembaga kearsipan perguruan tinggi menunjukkan budaya organisasi seluruh anggota yang dimiliki oleh lembaga tersebut. Bagaimanapun capaian mereka didalam berorganisasi merupakan hasil dari proses pemikiran, keputusan, tindakan, aturan, pengalaman yang diperleh selama saling berinteraksi didalam lembaga kearsipan perguruan tinggi. Dan profil yang nampak mewujudkan budaya organisasi yang khas melekat pada masing-masing lembaga kearsipan perguruan tinggi.

Etos kerja yang ditunjukkan oleh seluruh sumber daya manusia di Arsip UGM dan Kantor Arsip UI menunjukkan budaya organisasi yang melekat pada diri mereka. Jansen H. Sinamo (2009) membagi etos kerja dalam bisnis menjadi delapan etos kerja profesional. Mereka adalah etos satu "kerja adalah rahmat", etos dua "kerja adalah amanah", etos tiga "kerja adalah panggilan", etos empat "kerja adalah aktualisasi, etos lima "kerja adalah ibadah", etos enam "kerja adalah seni", etos tujuh "kerja adalah kehormatan", etos delapan "kerja adalah pelayanan”. Seluruh komponen ini disatukan menjadi etos kerja. Mencermati pandangan tentang etos kerja ini bila dilembagakan pada suatu organisasi akan menjadi budaya organsiasi yang positif. Positif bagi para anggota organisasi, bagi organisasi itu sendiri, juga bagi lingkungan organisasi tersebut. Kedua lembaga kearsipan perguruan tinggi yang ada di Indonesia ini telah membuktikan hal tersebut, bahwa budaya organisasi mereka telah mengantarkan bukan hanya bagi lembaga kearsipan tinggi tetapi juga bagi perguruan tinggi yang selalu menciptakan kreasi-kreasi baru yang bermanfaat secara luas sesuai dengan tujuan perguruan tinggi masing-masing. Satu hal yang perlu untuk selalu diingat adalah semua capaian itu berawal dari budaya masing-masing anggota organisasi.

\section{Simpulan}

Berdasarkan pada uraian tersebut di atas diketahui, bahwa masalah-masalah sumberdaya manusia kearsipan di Indonesia dapat dipetakan melalui sudut pandang keilmuan, yaitu organisasi, manajemen publik, kebijakan publik, budaya. Dari keseluruhan masalah-masalah sumber daya manusia keasipan pada perguruan tingg negeri di Indonesia, nampak bahwa kebijakan publik sangat dominan karena penyelenggaraan perguruan tinggi negeri merujuk pada kebijakan-kebijakan yang mengatur tentang penyelenggaraan pendidikan tinggi. Kebijakan publik yang dimaksud dalam penelitian ini terkait dengan kebijakan tentang pengadaan dan pengembangan sumber daya manusia kearsipan sebagaimana ketentuan 
yang telah diatur dalam Undang-Undang Nomor 43 Tahun 2009 tentang KearsipanKebijakan-kebijakan tersebut merupakan hasil dari proses politik yang dibuat pemerintah bersama lembaga legislatif.

Teori organisasi, manajemen publik dan budaya bersama-sama memiliki peran pada aspek teknis pelaksanaan kebijakan penyelenggaraan kearsipan perguruan tinggi. Penyelenggaraan kearsipan perguruan tinggi dilaksankan oleh unsur sumber daya manusia kearsipan. Sumber daya manusia kearsipan merupakan unsur di dalam organisasi yang dikoordinir oleh koordinator yang memimpin organisasi tersebut. Diperlukan struktur yang jelas pada organisasi sehingga tugas dan fungsi dari masing-masing organ tidak tumpang tindih dan memang keberadaannya memang diperlukan. Lembaga kearsipan perguruan tinggi memerlukan pemimpin yang berintegritas dan jujur beserta tim kerja yang memiliki etos kerja sehingga mereka bersama-sama menggerakkan roda organisasi sesuai dengan tujuan lembaga kearsipan perguruan tinggi tersebut.

Merujuk pada hasil pemetaan masalah-masalah sumber daya manusia kearsipan di Indonesia, maka komunikasi yang intens perlu dilakukan oleh lembaga kearsipan nasional selaku pembina kearsipan nasional dengan lembaga pemerintah terkait seperti Kemenpan RB, Kementerian Keuangan, Kementerian Riset, Teknologi dan Pendidikan Tinggi serta Rektor perguruan tinggi negeri di Indonesia. Selain itu para Kepala Lembaga Kearsipan Perguruan Tinggi Negeri juga melakukan komunikasi yang intens dengan Rektor dan pimpinan satuan kerja di seluruh organ yang ada di perguruan tinggi masing-masing untuk mentransmisikan kebijakan penyelenggaraan kearsipan. Diperlukan organisasi yang terstruktur dengan baik, pimpinan lembaga kearsipan perguruan tinggi yang berintegritas, serta anggota lembaga kearsipan perguruan tinggi sebagai organisasi kearsipan yang memiliki etos kerja tinggi.

\section{Daftar Pustaka}

admin, 2017. SKKNI:Standar Kompetensi Kerja Nasional Indonesia. https://sertifikasibnsp.com/skkni/skkni/ . Diakses tanggal 5 Desember 2017

Amir, Mohammad Faisal, 2016. Manajemen Kinerja Perguruan Tinggi, Jakarta, Mitra Wacana Media.

Arsip Universitas Indonesia, 2017. Kantor Arsip, http://arsip.ui.ac.id/tupoksi Diakses tanggal 23 Maret 2014

Arsip Universitas Indonesia, 2017. Kantor Arsip, http://arsip.ui.ac.id/tupoksi Diakses tanggal 7 Desember 2017

Arsip Universitas Indonesia, 2017. Kompetensi, http://arsip.ui.ac.id/node/29.\%20Diakses\%

2017\%20Mei\%202017 Diakses tanggal 17 Mei 2017)

Azmi, November 2015, "Strategi Peningkatan Daya Saing Tenaga Kerja Kearsipan Indonesia Mengahadapi Masyarakat Ekonomi ASEAN (MEA), Buletin Khazanah, Vol. 8, no. 3, pp 3-20

Batubara, 2010. Kebijakan Manajemen Arsip di Universitas Indonesia. http://leuwiliangbogor.blogspot.com/2010/05/kebijakan-manajemen-arsip-di.html. Diakses tanggal 12 Maret 2014

BruceW. Dearstyne, 2008. Leading and Managing Archives and Records Programs: Startegies For Success, New York, Neal-Schuman Publisher 
Direktorat Jenderal Pendidikan Tinggi Kementerian Riset, Teknologi, dan Pendidikan Tinggi Indonesia, 2017. Perguruan Tinggi, http://www.dikti.go.id/perguruan-tinggi/ Diakses tanggal 4 April 2017

Fitri, 2016. Seputar PTN-BH, PTN-BLU, PTN-Satker dan PTN-Baru. http://www.kopertis12.or.id/2016/05/16/seputar-ptn-bh-ptn-blu-ptn-satker-dan-ptn-baru.html,

Diakses 30 Januari 2017

Handayani, Tri, Desember 2012. Manajemen Arsip Perguruan Tinggi di Era New Public Service, Jurnal Kearsipan Vol. 7, no.1, pp.39-88

Hersiansyah, Haris, 2011. Metodologi Penelitian Kualitatif untuk Ilmu-Ilmu Sosial, Jakarta, Salemba Humanika

Humas UGM/Ika. 2017. Indonesia Kekurangan $140 \quad$ Ribu Arsiparis. https:// www.ugm.ac.id/id/news/13864-indonesia.kekurangan.140.ribu.arsiparis. $\quad$ Diakses $\quad$ tanggal 7 Desember 2017

Keesing, Roger M., 1999. Antropologi Budaya Suatu Perspektif Kontemporer. Alih Bahasa Samuel Gunawan, Jakarta, Erlangga

Kompasiana.com/Indriasari. 2012 Indonesia Arsiparis. http://edukasi.kompas.com/read/2012/05/15/20284782/Indonesia.Kekurangan.Arsiparis. Diakses tanggal 7 Desember 2017)

Kurniatun, Juli 2016, ”Kebijakan Pengembangan Arsiparis di Indonesia dan Tantangannya dalam Menghadapi Masyarakat Ekonomi Asean (MEA), Buletin Khazanah. Vol. 9, no.2, pp 15-30

Kusdi, 2009. Teori Organisasi dan Administrasi, Jakarta, Salemba Humanika

Sinamo, Jansen H, 2009. Etos Kerja Dalam Bisnis, Jakarta, Institut Darma Mahardika

Suara Merdeka. 2014. https://lintaskebumen.wordpress.com/2014/09/29/anri-tenaga-arsiparis-diindonesia-masih-minim/. Diakses tanggal 7 Desember 2017

Sudarmanto, 2015. Kinerja dan Pengembangan Kompetensi SDM: Teori, Dimensi Pengukuran, dan Implementasi dalam Organisasi, Yogyakarta, Pustaka Pelajar

Sukoco, Badri Munir. 2007. Manajemen Administrasi Perkantoran Modern. Jakarta, Erlangga .

Suwitri, Sri. 2011. Konsep Dasar Kebijakan Publik. Semarang: Badan Penerbit Universits Diponegoro

Utomo, Warsito, 2006. Administrasi Publik Baru Indonesia: Perubahan Paradigma dar Administrasi Negara ke Administrasi Publik. Yogyakarta, Kerjasama Program Magister Administrasi Publik dengan Pustaka Pelajar

Wikipedia, 2017. Perguruan Tinggi Negeri Badan Hukum. https://id.wikipedia.org/wiki/Perguruan Tinggi Negeri Badan Hukum, Diakses tanggal

\section{Wawancara}

Wawancara dengan Anon Mirmani 25 Oktober 2015 
